
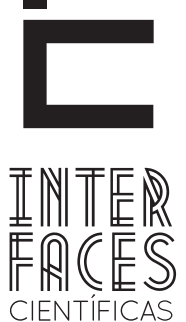

DIREITO

\title{
DO DIREITO CONTRATUAL LIBERAL AO [UM POUCO) SOCIAL: APONTAMENTOS SOBRE A IMPREVISÃO CONTRATUAL E OS DIREITOS FUNDAMENTAIS
}

Douglas Policarpo ${ }^{1}$

\section{RESUMO}

O Estado Liberal foi resposta da burguesia relativamente à excessiva intervenção do Estado nas relações privadas. Para tanto, o direito acabou se desenvolvendo e foram revelados diversos institutos que eram considerados sacros, tais como a autonomia privada e o pacta sunt servanda. No início do século XX, com o surgimento do Estado do bem estar social, acabou sendo necessário que este avocasse para si a função de diminuir o abismo social, resultante da total ausência de intervenção. Assim, a autonomia da vontade sofreu drástica mudança com o advento do novo texto constitucional, o qual trouxe para o primeiro plano o valor do ser humano, vivente em uma coletividade e portador de dignidade. Com isso, diversos princípios passaram a incidir nas relações jurídicas privadas - eficácia horizontal dos direito fundamentais - sobretudo, porque sob a antiga ótica civilista, o ideal supremo - especialmente na seara contratual - era a ilimitada autonomia da vontade, fixada e congelada no tempo pelo instituto do pacta sunt servanda. As-
Carolyne Silvestre Oliveira Mendes²

sim, com o advento do atual Código Civil em 2002, o ordenamento jurídico brasileiro deu mais um passo na relativização desses antigos institutos, perdendo espaço agora para os princípios humanos positivados, aqui em foco, pela legislação infraconstitucional, incidindo diretamente nos contratos. Dessa forma, busca-se, utilizando o método dedutivo de abordagem e por técnica de pesquisa a bibliográfica em fontes secundárias, analisar, com base na doutrina, legislação e jurisprudência, a teoria da onerosidade excessiva como expressão da dignidade da pessoa humana e dos direitos fundamentais nas relações jurídicas entre os particulares.

\section{PALAVRAS-CHAVE}

Relações Jurídicas Privadas. Eficácia Horizontal dos Direitos Fundamentais. Dignidade da Pessoa Humana. Autonomia da Vontade. Teoria da Onerosidade Excessiva. 


\section{ABSTRACT}

The Liberal State was response to the bourgeoisie in relation to excessive state intervention in private affairs. Therefore, the right to develop and eventually were revealed several institutes which were considered sacred, such as private autonomy and pacta sunt servanda. In the early twentieth century, with the rise of the welfare state, eventually need that this ended up attracted to itself the function of reducing the social divide, resulting from the complete absence of intervention. Thus, the autonomy of the will suffered drastic change with the advent of the new constitutional text, which brought to the foreground the value of the human being, living in a community and the bearer of dignity. With this, several principles have come to focus on private legal relations - horizontal effect of fundamental rights especially because under the old optical civilist, the supreme ideal - especially in harvest contract - was the unlimited autonomy of will, fixed and frozen in time by institute of pacta sunt servanda. Thus, with the advent of the present Civil Code in 2002, the Brazilian legal system has taken another step in the relativization of these old institutions, now losing ground to the human principles positivized, here in focus, by constitutional legislation, focusing directly on contracts. Thus, looking up, using the deductive method of approach and technique for the research to bibliographic on secondary sources, analyze, based on the doctrine, legislation and jurisprudence, the theory of excessive burden as an expression of human dignity and fundamental rights in legal relationships between individuals.

\section{KEYWORDS}

Private Legal Relations. Horizontal Effectiveness of Fundamental Rights. Human Dignity. Autonomy of the Will. Theory of Excessive Burden.

\section{RESUMEN}

El Estado liberal de fue la respuesta de la burguesía en relación a la excesiva intervención estatal en los asuntos privados. Por eso, el derecho se fue desarrollando $y$, finalmente, se dieron a conocer varios institutos que se consideraban sagrado, como la autonomía privada y el pacta sunt servanda. A principios del siglo XX, con el surgimiento del Estado de bienestar social, se hizo necesario que este asumiera para sí la función de reducir el abismo social resultante de la ausencia total de intervención. Por lo tanto, la autonomía de la voluntad sufrió un cambio drástico con la llegada del nuevo texto constitucional, que puso en primer plano el valor del ser humano, que vive en una comunidad y es portador de dignidad. Con esto, una serie de principios pasaron a influir en las relaciones jurídicas privadas - eficacia horizontal de los derechos fundamentales - sobre todo porque, bajo la antigua visión civilista, el ideal supremo - especialmente en el contrato - era la ilimitada autonomía de la voluntad, fijada y congelada en el tiempo por principio del pacta sunt servanda. Así, con el advenimiento del actual Código Civil en el año 2002, el sistema legal brasileño ha dado un paso más en la relativización de estos antiguos principios, ahora perdiendo terreno frente a los principios humanos positivados, enfocado aquí, por la legislación infraconstitucional, centrándose directamente en contratos. Por lo tanto,se busca, utilizando el método deductivo de enfoque y la técnica de la literatura de investigación en fuentes secundarias para analizar, basado en la doctrina, la legislación y la jurisprudencia, la teoría de la carga excesiva, como expresión de la dignidad humana y los derechos fundamentales en las relaciones jurídicas entre los individuos.

\section{PALABRAS CLAVE}

Relaciones Jurídicas Privadas. Efectividad Horizontal de los Derechos Fundamentales. Dignidad de la Persona Humana. Autonomía de la Vonluntad. Teoría de la Carga Excesiva. 


\section{INTRODUÇ̃̃̃O}

O contrato, um dos principais responsáveis pela circulação de bens, encontra sua razão de ser na vontade. É este, o fator volitivo, que vinculado ao Direito faz nascer obrigações recíprocas, que se tornam obrigatórias entre os pactuantes.

Todavia, este fator preponderante é responsável por originar obrigações que a todo custo deveriam ser cumpridas. E encontram-se hoje como será visto no transcorrer do estudo, relativizado.

Sob a vigência do Código Civil de 1916 não havia que se falar em limites a autonomia da vontade ${ }^{1}$. Em um diploma onde o essencial era a proteção dos bens, sua destinação e as relações que se desenvolviam em seu entorno, a vontade deveria ser ampla e ilimitada, pois se entendia que as partes estavam em patamares iguais e eram capazes de assumir compromissos através de uma negociação plena e equitativa que depois de firmada passaria a reger aquela relação, fazendo lei entre as partes.

Era assim que o contrato era visto, como uma lei. E como lei deveria ser respeitada, não se cogitando a hipótese de acontecimentos que pudessem dificultar o seu cumprimento, proporcionando para uma das partes, ou até para ambas, a revisão ou resolução contratual.

É nesta circunstância que cumpre destacar outro ponto do presente estudo, qual seja, a incidência dos direitos fundamentais nas relações jurídicas privadas. Isto, porque, são os direitos fundamentais os principais responsáveis pela mudança de paradigmas jurídicos enfrentada pela sociedade, que culminou com 0 advento da nossa Constituição Federal em 1988, bem como com o Novo Código Civil em 2002.

\footnotetext{
1 Será utilizado neste texto os termos autonomia da vontade, autonomia volitiva e autonomia privada indistintamente, ou seja, como sinônimos; não adentrando em discussão acerca do melhor vocábulo.
}

Os horrores das guerras, oriundos principalmente daquelas que ocorreram no início do século XX, fizeram com que a população sentisse os resultados de vontades desmedidas, desenfreadas e impostas. Nesse sentido, visualizou-se que, sob pena de serem cometidas novas barbáries, necessário seria impor limites às vontades e atribuir novas roupagens a princípios ou valores antes absolutos.

Foi este cenário que fez com que caísse a venda do constituinte e se criassem limites positivados e com a pretensão de respeito por todos, frente à realidade humana, independente das diferenças.

Nesse diapasão, buscar-se-á, no presente trabalho, utilizando o método dedutivo de abordagem e por técnica de pesquisa a bibliográfica em fontes secundárias analisar a teoria da onerosidade excessiva, defendendo-a como um direito fundamental inerente a relação contratual, por entender-se que tal teoria encontra-se intrinsecamente ligada a dignidade da pessoa humana. Também, discorrer-se-á, após se traçar o caminho necessário para a devida compreensão, que o reino da vontade ainda é amplo, todavia, bem menor que o vigente há alguns anos atrás.

Assim, para alcançar este ponto será necessário delinear linhas introdutórias acerca das formas de incidência dos direitos fundamentais nas relações privadas.

Com efeito, serão relacionados interesses, aparentemente contrapostos, uma vez que aonde vigora a dignidade da pessoa humana e os direitos fundamentais, também incide a autonomia da vontade, norteadora de inúmeras tratativas que, agora estão balizados não apenas pela ordem civil, mas principalmente por valores constitucionais.

Assim sendo, a conclusão se dá pela aplicação total e irrestrita dos direitos fundamentais nas relações 
entre particulares, sob o fundamento de preservação e prestígio do princípio dos princípios, qual seja a dignidade da pessoa humana, como será desenvolvido

\section{A INCIDÊNCIA DOS DIREITOS FUNDAMENTAIS NAS RELAÇÕES JURÍDICAS PRIVADAS}

Os direitos fundamentais, inicialmente, visavam a proteção dos indivíduos contra as ingerências estatais; desta feita, emanavam dos indivíduos e teriam como principais destinatários os Poderes Públicos. Isso aconteceu porque, com a passagem do Estado absolutista para o Estado liberal, a observância dos direitos fundamentais passou a ser escorreita, precipuamente, contra o Estado, reservando-se ao Direito Privado a regência das relações firmadas entre os particulares (MARTINEZ apud RODRIGUES GOMES, 2005, p. 51).

O Estado liberal de Direito, a partir do século XIX encontrou, no conceito de Direito Subjetivo Público, as palavras necessárias para adequar os direitos fundamentais aos seus destinatários. Ou seja, as limitações criadas pelo Estado e aplicadas a si mesmo já elucidavam as dúvidas quanto aos destinatários destes direitos. Corroborando com esse modelo amplamente difundido no Estado liberal, tinha-se a dicotomia visível e bem delimitada de Direito Público e Direito Privado. Dessa forma, não entrava na pauta de discussão a aplicação de direitos fundamentais no campo jurídico privado, pois este sítio era regido por leis próprias e a Constituição ainda não possuía qualquer valor que the conferisse supremacia; era vista apenas como uma simples diretriz estatal (PEREIRA, 2008) de organização política.

Entretanto, esta estrutura foi abalada com o advento das grandes guerras mundiais, principalmente com as atrocidades cometidas contra os seres huma- em situação específica da aplicação da teoria da imprevisão nas relações civis contratuais.

nos. Os direitos humanos ${ }^{2}$ voltaram à tona e, desta vez, os seus destinatários não eram mais os mesmos do Estado liberal. Reflexo desta mudança de paradigma encontra-se nas Constituições elaboradas no pós-guerra e ao poder que passou a ser indissociável a este tipo de norma: a supremacia da ordem constitucional. 0 que antes era tido como subsidiário, passou a ser o essencial (PEREIRA, 2008).

Nesse caminho, percebeu-se que era necessário transpor os até então limites constitucionais dos direitos fundamentais e trazê-los para o campo onde, anteriormente pautado pelo valor supremo da autonomia da vontade e da legalidade, foram praticadas incontáveis barbáries em relação aos aparentemente desprovidos de dignidade humana (RODRIGUES GOMES, 2005).

Como consequência deste período nebuloso da história mundial, surgiu a necessidade de criação de mecanismos inibidores de novos embates. Se antes a liberdade livre e desmedida reinava no campo privado, agora ela passou a encontrar 'limites'. Estes limites, consoante José Joaquim Gomes Canotilho (2003), teriam sua origem na esfera constitucional e contemporaneamente são conhecidos pela denominação de eficácia horizontal dos direitos, ou das liberdades e ou das garantias fundamentais.

2 E foi nesse cenário, após a humanidade assistir horrores praticados po seres humanos contra seres humanos - ambos guiados pelas suas convicções e vontades -, que, em âmbito internacional, surgiu a Declaração Universal dos Direitos Humanos (1948) que expôs e expressamente consignou os valores fundamentais próprios dos seres humanos (BOBBIO, 2004, p. 33). 
Dessa forma, tentando assegurar a autonomia da vontade, principal lastro das relações jurídicas privadas e garantir a aplicação dos direitos fundamentais nesta mesma seara, coibindo consequentes abusos,

\subsection{TEORIA DA EFICÁCIA INDIRETA OU MEDIATA}

A teoria da eficácia indireta apregoa que as normas fundamentais, ao serem aplicadas no seio social privado, deveriam o ser de maneira indireta, buscando salvaguardar a liberdade predominante na celebração do acordo de vontades. Ou seja, preservando a autonomia da vontade de tal forma que, os valores fundamentais oriundos da ordem constitucional só encontrariam respaldo para serem aplicados indiretamente, pela via legislativa. Fora isto, a autonomia da vontade não poderia ser limitada.

Esta posição, sedimentada na interpretação alemã e fundamentada na segurança jurídica, cujo objetivo é evitar a violação de princípios maiores, como o democrático, apregoa que, ao juiz, seria defeso atuar fora dos parâmetros trazidos pelo legislador (RODRIGUES GOMES, 2005, p. 55).

Discorrendo sobre esta teoria e reforçando a ideia trazida acima, tem-se a lição de José Joaquim Gomes Canotilho, afirmando que,

\subsection{TEORIA DA EFICÁCIA DIRETA OU IMEDIATA}

Já a teoria da eficácia direta ou imediata, caracteriza-se pela aplicação direta dos direitos fundamentais nas relações travadas no mundo jurídico privado (CANOTILHO, 2003). O labor legislativo, neste campo, deixa de ser o intermediador da aplicação dos direitos, liberdades e garantias, como ocorre quando a discussão baseia-se na eficácia indireta ou mediata. sobrevieram, principalmente, duas teorias: teoria da eficácia direita ou imediata e teoria da eficácia indireta ou mediata.

os direitos, liberdades e garantias teriam uma eficácia indirecta nas relações privadas, pois a sua vinculatividade exercer-se-ia prima facie sobre o legislador, que seria obrigado a conformar as referidas relações obedecendo aos princípios materiais positivados nas normas de direito, liberdades e garantias". (2003, p.1286-1287)(sic).

Nesta toada, pertenceria ao legislador o arbítrio de positivar preceitos que permitissem aos juízes, frente a casos concretos levados ao seu conhecimento, emitir seu parecer sobre a incidência ou não de um direito fundamental naquela relação jurídica privada concreta. A segurança jurídica, dessa forma, estaria protegida. Os defensores da aludida teoria temiam que frente a uma incidência direta dos direitos fundamentais, a vontade dos pactuantes aproximasse-se do patamar da inexistência, restando praticamente suprimida.

Destarte, havendo ou não lei proibitiva ou permissiva, "e de o ajuste de vontades ter sido efetuado com amparo na autonomia individual, o caráter normativo da Constituição exigiria a consideração imediata dos direitos fundamentais por ela consagrados" (RODRIGUES GOMES, 2005, p. 31). 
Assim, vê-se que essa teoria se coaduna com a adotada pelo constituinte originário brasileiro, pois, 0 art. $5^{\circ}$, parágrafo primeiro, da Constituição Federal declara que deverá ter aplicação imediata das normas definidoras de direitos e garantias fundamentais.

Contudo, afora o texto constitucional brasileiro, a problemática de incidência dos direitos fundamentais na ordem privada não resta pacificada. E, buscando solucionar, ou ao menos, compatibilizar as duas teorias e os seus respectivos âmbitos de atuação, Canotilho (2003, p. 1289) afirma que deverá haver definitivamente uma superação desta dicotomia com o fito de se buscar soluções diferenciadas, levando-se em conta a "multifuncionalidade ou pluralidade de funções dos direitos fundamentais".

Desta feita, percebe-se que a solução adequada deverá ser buscada e aplicada consoante a faceta do direito fundamental em discussão, vez que é de suma importância que "a procura de soluções diferenciadas deve tomar em consideração a especificidade do direito privado, por um lado, e o significado dos direitos fundamentais na ordem jurídica global por outro" (CANOTILHO, 2003, p. 1289).

\section{A AUTONOMIA DA VONTADE COMO SUSTENTA- ÇÃO DAS RELAÇÕES PRIVADAS}

Assim, como já expressado alhures, como corolário do direito contratual, tem-se a vontade; e é esta a responsável por originar o contrato. "Contrato sem vontade não é contrato. Pode ser tudo. Até tirania. Menos contrato" (GAGLIANO; PAMPLONA FILHO, 2005, p. 40). No mesmo sentido, a lição de Orlando Gomes (1984, p. 25):

O princípio da autonomia da vontade particulariza-se no direito contratual na liberdade de contratar. Significa o poder dos indivíduos de suscitar, mediante declaração de vontade, efeitos reconhecidos e tutelados pela ordem jurídica. [...] Outros conceituam a autonomia da vontade como um aspecto da liberdade de contratar, no qual o poder atribuído aos particulares é o de traçar determinada conduta para o futuro, relativamente às relações disciplinares da lei.

Desta maneira, retoma-se que, inicialmente vigorava o Estado Liberal e nessa ideologia não havia que se falar em limites a autonomia volitiva. Pensava-se nas pessoas como iguais, e consequentemente, poderiam estabelecer o acordo livremente, cada qual sabendo negociar o que lhe era válido para alcançar seus objetivos nas relações jurídicas travadas.

Essa igualdade, dita formal, constante unicamente na lei abstrata, fez com que a ordem jurídica direcionasse seus esforços para outro norte. Pontua Orlando Gomes (1984) que o ordenamento jurídico, por entender as partes iguais, acreditava que qualquer discussão travada para se chegar ao contrato, seria finalizada com o alcance de um denominador comum, "partes iguais e livres não precisavam de interferência legislativa para impedir a estipulação de obrigações onerosas ou vexatórias".

Corroborando com este entendimento, Cassio $\mathrm{M}$. C. Penteado Jr. (2003), pontua que o Código Civil de 1916 apregoava uma liberdade ampla porque, aparentemente, as partes estariam em patamares iguais, e os interesses que estavam sendo discutidos seriam, salvo exceções legais, disponíveis. Dessa forma, sob o manto da autonomia da vontade, os contratos seriam pactua- 
dos e as partes, já que formalmente iguais, se submeteriam aquelas condições que ficaram ajustadas.

Assim sendo, firmou-se o entendimento de que no âmbito dos contratos deveria prevalecer de forma suprema a vontade. Era ela quem criava as normas pri- vadas que regeriam livremente os pactos, fazendo daí nascer direitos e obrigações entre as partes. Em relação à vontade livre, não caberia qualquer intervenção estatal. A supremacia de sua existência era garantida pelo próprio sistema jurídico.

\section{A INSERÇ̃̃̃O DE VALORES ÀS RELAÇÕES PRIVA- DAS E O REPOSICIONAMENTO DA AUTONOMIA DA VONTADE}

Apesar de ter garantida a igualdade formal entre as pessoas, materialmente elas continuavam em patamares distintos, gerando a necessidade da inserção de valores humanos-sociais, a fim de que fossem impedidas e respeitadas as diferenças de uns, frente os outros. Para tanto, vislumbrou-se a impossibilidade de deixar a relação contratual prosseguir ao livre arbítrio dos pactuantes, pois contratos válidos, firmados com base na autonomia volitiva, estavam ocasionando benefícios inimagináveis a uma das partes, em prejuízo de gravames insuportáveis a outra.

Assim, na contramão das ideologias do Estado Liberal, marcado pelo amplo individualismo e na crença de igualdade entre os seres humanos, surgiu o Estado Social, caracterizado por intervir na ordem econômica e social, através de atuações das esferas administrativa, legislativa e judicial (LÔBO, 2002).

Nesse diapasão, e principalmente após o advento da Carta Constitucional de 1988, percebeu-se que a força da autonomia da vontade, praticamente absoluta sob a ótica do Codex antigo, deveria ser revista. A vontade, antes ditadora das regras que originariam o pacto, deveria sofrer um reposicionamento, encontrando limites.

Surgiram, então, valores sociais-humanos que deveriam incidir diretamente na relação jurídica pri-

vada, valores esses que encontravam na Constituição sua morada e, por isso, deveriam ser aplicados, independentemente de ocasionarem diminuição ou não da autonomia da vontade das partes.

No mesmo sentido, Flávio Tartuce (2007) destaca a necessidade de compatibilizar a vontade dos contratantes com outros valores, como os dos direitos fundamentais, a dignidade da pessoa humana e os diversos institutos que derivam destes. Pois, a sociedade contemporânea civilista, não permite mais a vigência de direitos absolutos.

Além do que, embasados na ordem constitucional vigente, entende-se ser necessário pautar as relações jurídicas privadas não apenas no seu fim econômico, mas no seu fim social. Assim, é possível afirmar, na esteira de Konrad Hesse (2009, p. 61), que "nas relações entre particulares, todos os interessados compartilham da proteção dos direitos fundamentais". De outro lado nada adiantaria o constituinte originário prever a dignidade da pessoa humana como fundamento da República Federativa do Brasil e permitir que legislações infraconstitucionais a violassem em busca de interesses individuais, desprovidos de qualquer respeito à sociedade e aos direitos garantidos. 
Nessa esteira, valores oriundos da dignidade da pessoa humana, travestidos de teorias ou princípios, passaram a limitar a autonomia da vontade, como se vislumbra pela incidência da teoria da onerosidade excessiva, como será visto a seguir.

\section{A AMPLITUDE E EFETIVIDADE DO PRINCÍPIO DA DIGNIDADE DA PESSOA HUMANA NAS RELA- ÇÕES JURÍDICAS PRIVADAS}

Os direitos fundamentais possuem uma posição de destaque no ordenamento jurídico, encontrando-se inseridos no topo deste sistema (ALEXY, 2006). E foi com o advento do novo texto Constitucional, em 1988, que se experimentou um avanço jamais visto no tocante a proteção dos direitos e garantias fundamentais, pois, além de terem sido elencados pormenorizadamente, tiveram um aumento significativo na amplitude de seu rol, o que colocou a atual Constituição Federal entre as Cartas Magnas mais avançadas com relação a este particular (PIOVESAN, 2009).

Como dito anteriormente, foi a dignidade da pessoa humana que atribuiu novas tonalidades aos princípios clássicos do direito contratual e passou também a servir de parâmetro para qualquer relação jurídica, dentro ou fora da área privada. Foi ela também, e é ela ainda, que confere o caráter insubstituível a cada ser humano; afinal, cada qual é portador de um valor próprio - a própria dignidade (COMPARATO, 2010).

Pablo Stolze Gagliano e Rodolfo Pamplona Filho (2005) afirmam que no Direito Civil contemporâneo, os bens cederam lugar a pessoa humana, e como consequência desse novo paradigma, os princípios adquiriram uma nova roupagem; como um novo atributo, não apenas da seara contratual, mas no direito como um todo.

Nesse norte, a dignidade da pessoa humana ao ser trazida como fundamento da República, pela Constitui- ção de 1988, mudou o enfoque do ser humano individualmente considerado para o ser humano enquanto ser vivente de uma coletividade, fruto de interações com inúmeros outros seres humanos (POLICARPO, 2006).

Primar pela dignidade da pessoa humana e pela observância dos direitos fundamentais nas relações jurídicas privadas traz ínsita a ideia de que ambos os conceitos encontram-se umbilicalmente ligados. Nessa esteira, cabe colacionar o entendimento de Ingo Wolfgang Sarlet (2010), segundo o qual a dignidade da pessoa humana encontra-se atrelada, indissociavelmente, aos direitos fundamentais. Tal vinculação é um dos pilares do direito constitucional contemporâneo. Isto ocorre até mesmo onde a ordem constitucional não previu a dignidade. Ou quando, apesar de positivada, ela não transpõe os limites do texto constitucional.

Assim, este princípio supremo oriundo em âmbito interno da atual Carta Magna, não poderá ser ultrapassado sem antes ser respeitado. Deverá ser observado em todas as etapas contratuais, seja na elaboração, seja na execução contratual. Pois, o valor fundamental defendido, o respeito aos seres humanos e as suas necessidades enquanto pertencentes a esta espécie, não poderão ser objeto de restrições do Direito Privado.

Nesse diapasão, cumpre trazer a lume a lição de Sarlet (2010, p. 49-50): 
a dignidade, como qualidade intrínseca da pessoa humana, é irrenunciável e inalienável, constituindo elemento que qualifica o ser humano como tal e dele não pode ser destacado, de tal sorte que não se pode cogitar na possiblidade de determinada pessoa ser titular de uma pretensão a que the seja concedida a dignidade. Assim, compreendida como qualidade integrante e irrenunciável da própria condição humana, a dignidade pode (e deve) ser reconhecida, respeitada, promovida e protegida, não podendo, contudo (no sentido ora empregado) ser criada, concedida ou retirada (embora possa ser violada), já que reconhecida e atribuída a cada ser humano como algo que the é inerente.

Dessa forma, vislumbra-se que todos os seres humanos são possuidores de dignidade, não sendo necessário que a sociedade assim o reconheça e um ordenamento jurídico garanta a quem quer seja, sendo possíveis as legislações, independente de hierarquia, apenas assegura-la no sentindo de que entes estatais (e também particulares) empreendam esforços que culminem com a sua mais alta proteção e observância.

Assim, a dignidade não deve ser um valor passível de ser retirado de um ser humano, uma vez que se trata de um bem indisponível, não relativo. Os seres humanos são iguais em dignidade, não havendo hierarquia entre a dignidade de uma ou outra pessoa. E mais, frente a sua não relatividade, não é possível negar a uma pessoa a dignidade, uma vez que, se isto ocorresse, não se estaria mais a considerar como um ser humano (MAURER, 2009).

Nesse sentindo, a “dignidade constitui a um só tempo pressuposto e condição para que se viva em sociedade, e exige limitação ao poder de toda autoridade ou mesmo pessoal de atingi-la ou desrespeitá-la [...]" (POLICARPO, 2006, n.p.). Portanto, a dignidade da pessoa humana deverá incidir não apenas entre particulares e Estado, mas também, e principalmente, entre os próprios seres humanos em suas relações privadas.

Será possível, ainda na seara de incidência e abrangência do valor supremo em comento, um respeito recíproco dos membros da sociedade, antes da intervenção judicial. Pois, como já dito, ainda que ausente a atividade legislativa, será lícito ao magistrado solucionar o impasse daquele que se socorreu do poder jurisdicional, visando obter um pronunciamento acerca da violação ou restrição de um direito que possui enquanto ser humano.

Ora, é defeso ao julgador, bem como a pessoa humana, atribuir valor diverso aquele conferido pela Constituição Federal aos direitos e valores constantes em seu texto. Diga-se: se a ordem constitucional balizou todo o ordenamento naquilo que foi considerado fundamental, não pode um ser humano, seja ele quem for, mudar o enfoque destes direitos e valores, pois se assim agisse, corrompendo estaria a Constituição, e via de consequência, todas as normas jurídicas nela fundada (PIOVESAN, 2010).

Assim, Maria Helena Diniz (2009) preleciona que a intervenção estatal se dá não somente com a edição e aplicação de leis, mas também pela via judicial. Já que ao juiz é conferido o poder de rever o acordo contratual quando presentes requisitos que assim justifiquem essa atividade, chegando ao ponto de, dependendo do caso concreto, exonerar a parte lesada do cumprimento da prestação.

Dessa forma, a intervenção judicial, em território contratual, encontra sua razão de ser no valor constitucional da dignidade, pois, não é possível exigir esforços sobre humanos e uma vida pautada em sacrifícios apenas para cumprir um pacto que, no momento da celebração era valioso para ambos, mas que, por motivos adversos e imprevisíveis, passou a prejudicar demais uma das partes.

Outro não é o fundamento dos princípios contratuais trazidos pelo atual Código Civil. E mais, a dignidade também é o pilar dos princípios oriundos de outras épocas jurídicas, pois, ainda que nascidos sob a vigência de outras leis, a nova interpretação ou aplicação que lhe são atribuídos advém do valor supremo inerente a todo ser humano. 
Na lição de Paulo Luiz Netto Lôbo (2002), os princípios dos contratos atinentes ao Estado Social são: a) princípio da função social do contrato; b) princípio da boa-fé objetiva e; c) princípio da equivalência material do contrato. E ainda, o ilustre professor traz os princípios oriundos do Estado Liberal, e.g., a autonomia privada que continuam a vigorar, contudo, agora limitados pelos novos princípios que deverão revestir os antigos.

Outro limite enfrentado pela autonomia da vontade é a função social do contrato, "São dois princípios antagônicos que exigem aplicação harmônica" (LÔBO, 2002, p. 17). A função social contratual encontra-se positivada no Código Civil, no art. 421, e indiretamente positivada na Constituição Federal. Indiretamente porque, a função social trazida pela Carta Magna diz respeito à propriedade, contudo, estende-se aos contratos, pois este surgiu com aquela, e aquela é adquirida, na maioria dos casos, pela via contratual. (GAGLIANO; PAMPLONA FILHO, 2005).

Lôbo pontua, ainda, que há outro dispositivo constitucional a consagrar a função social. Seria ele o art. 170 da CF, correspondente ao título da Ordem econômica e financeira, ao estabelecer que a ordem econômica deverá respeitar os preceitos da justiça social. Vincula-se este dispositivo a função social contratual, pois, é este um dos instrumentos utilizados para o alcance de atividades mercantis. Assim, restará presente a função social enquanto sobreviver a Ordem econômica do país. Nas sábias palavras de Lôbo (2002, p. 16), "enquanto houver ordem econômica e social, haverá Estado social; enquanto houver Estado social, haverá função social do contrato".

E assim, a ampla, ilimitada, imensurável e suprema autonomia da vontade passou a ser balizada por outros valores e princípios, como a já dita dignidade da pessoa humana, a qual se apresenta como fundamento de outros princípios como o da função social do contrato, da boa-fé objetiva e a teoria da imprevisão. Aquela pode ser alcançada através da busca do desenvolvimento social pela via contratual. Ou seja, o contrato deverá, não apenas atender os interesses dos pactuantes, mas também buscar o bem comum (GAGLIANO; PAMPLONA FILHO, 2005).

Ainda para esses autores “[...] Há interesse de que o contrato seja socialmente benéfico, ou, pelo menos, que não traga prejuízos à sociedade - em suma, que o contrato seja socialmente justo" (SANTOS apud GAGLIANO; PAMPLONA FILHO, 2005, p. 54-55).

0 contrato deixou de ser apenas uma manifestação da vontade privada, e passou a ser um "elemento socialmente agregador" (GAGLIANO; PAMPLONA FILHO, 2005, p. 561). A função social passou a limitar os interesses individuais e a condicioná-los ao bem geral. Sempre que presentes, os interesses sociais deverão servir de parâmetro para a incidência dos interesses individuais. Devendo, inclusive, em casos de possíveis conflitos, aqueles prevalecerem sobre estes (LÔBO, 2002, p. 15).

Dessa forma, visualiza-se que o contrato hodierno é fruto de diversos outros valores e, não mais, apenas da vontade dos contratantes. Contudo, a vontade não foi extirpada do ordenamento vigente e, ainda que reduzida, ela continua a existir e formar relações jurídicas entre seres humanos. 0 que ocorreu, principalmente, após o advento do texto constitucional de 88 , foi o redirecionamento do enfoque da relação privada, antes centrada nos bens e agora redimensionada para a pessoa, para ser humano, este portador de vontade, mas, também, e principalmente, de dignidade. 


\section{A TEORIA DA IMPREVISÃO NAS RELAÇ̃̃ES PRI- VADAS CONTRATUAIS}

O Código Civil de 1916, cuja origem remonta ao Código Napoleônico, era pautado no indivíduo e nas relações que este travava em torno de seu patrimônio, v.g., a propriedade. "O Código Civil Brasileiro, como os outros códigos de sua época, era a Constituição do direito privado" (TEPEDINO, 2004, p. 02). Era este estatuto civilista o responsável por regular a relação entre as riquezas, sua circulação e o indivíduo. E, justamente por isso, visando proteger os bens, é que o pacto firmado entre os indivíduos deveria ser respeitado e cumprido fielmente. 0 contrato fazia lei entre as partes. Passava a vigorar, assim, em território pátrio, o pacta sunt servanda.

A premissa básica estabelecida pelo pacta sunt servanda era que o contrato, uma vez concluído, devia ser respeitado e cumprido pelas partes, não podendo ser modificado pela vontade unilateral de apenas um contratante. Nessa esteira, tem-se o escólio de Sílvio de Salvo Venosa (2003, p. 461), ao trazer que "[...] uma vez concluído o contrato, deve ele permanecer incólume, imutável em suas disposições, intangível por vontade unilateral de um dos contratantes".

A imutabilidade contratual se dava em virtude do papel desempenhado pelo contrato na sociedade do século XX, e pelo papel que continua a exercer na atual sociedade: regular a circulação de riquezas. Com efeito, entabulado um pacto com arrimo na vontade livre, deveria ser ele fielmente cumprido, já que acreditavam serem os contratantes e, consequentemente todos os indivíduos, iguais (FIUZA, 2003).

Pertencia ao contrato o dever de regulamentar um sem número de relações jurídicas, não apenas privadas, mas públicas também. E, com o intuito de proteger esse emaranhado de relações é que se dizia que o contrato fazia lei entre as partes. Entendia-se que, outro não era o objetivo do pacta sunt servanda que não a segurança jurídica.
No escólio de Orlando Gomes (1984, p. 38), tem-se que o contrato, sob a ótica da intangibilidade, é tido como lei entre as partes; se, no momento da celebração, os requisitos necessários a sua validade foram respeitados, não há que se falar em descumprimento em virtude de alterações das condições. Arremata dizendo que "a força obrigatória atribuída pela lei aos contratos é a pedra angular da segurança do comércio jurídico".

Todavia, com o advento da Constituição Federal em 1988 e a entrada em vigor do atual Código Civil, no início de 2003, o individualismo perdeu espaço para uma nova geração de direitos agora pautados na dignidade da pessoa humana e nos direitos fundamentais. 0 legislador passou, então, a direcionar seus esforços a proteger o ser humano, sem, contudo deixar de conferir proteção também às relações que este pactuava com outros seres da mesma espécie. Nessa toada, estreme de dúvida, foi assegurada, expressamente, a proteção aos direitos fundamentais e a dignidade da pessoa humana.

Como norteador dessa nova era contratual instaurada, tem-se a teoria da imprevisão que, adotada pela legislação pátria - no art. 478 do Código Civil - sob o enfoque da onerosidade excessiva, estabelece que, aos contratantes será devido se socorrer do judiciário para resolver ou alterar o contrato que ocasione gravames imprevisíveis e insuportáveis, gerando enorme dificuldade ao seu cumprimento e ocasionando onerosidade excessiva a uma, ou ambas as partes.

Entende-se que a teoria da imprevisão possa ser utilizada como sinônimo da cláusula rebus sic stantibus, tendo apenas em mente que a origem desta é remota, encontrando sua primeira previsão, ainda que sutilmente, no Código de Hamurabi, em sua lei 48. 
Reportada cláusula, abreviação da fórmula contractus qui habent tractum sucessivum et dependentiam de futuro, rebus sic stantibus, preconizava que o cumprimento dos contratos, quando estes fossem a termo ou de trato sucessivo, estava sujeito a mantença do estado das coisas de quando o foi pactuado. “[...] 0 vínculo obrigatório se entendia subordinado à continuação daquele estado de fatos vigente à época da contratação" (SILVA FILHO, 1993, p. 128).

Em Roma, era possível vislumbrar a cláusula em comento, contudo, seu nascedouro foi a doutrina católica dos séculos XII e XIII, oriunda, principalmente, dos pensamentos de São Tomás de Aquino e Santo Agostinho (SILVA FILHO, 1993).

A necessidade de positivar a cláusula rebus sic stantibus surgiu com o advento da Primeira Grande Guerra Mundial, responsável por gerar grandes mudanças no cenário mundial. Nessa toada, caberia a revisão contratual oriunda do estado de guerra se "o cumprimento das obrigações por parte de qualquer contratante the causasse prejuízos cujo montante excedesse de muito a previsão que pudesse ser feita, razoavelmente, ao tempo de sua celebração" (GOMES, 1984, p. 40).

Outro não foi o objetivo da Lei Failliot, na França, em 1918 que, positivou, no período pós-guerra, a possibilidade de revisão contratual aos pactos firmados antes do desencadear deste conflito mundial.

Dessa forma, passou-se a entender que, nos contratos de execução continuada ou diferida, o pacto permaneceria vigente enquanto as condições em que foi firmado encontrassem-se presentes. Caso o verificado fosse o contrário, poderia se falar em revisão contratual com base na alteração do estado das coisas e na existência implícita da cláusula rebus sic stantibus.

A intangibilidade, na sábia lição de Orlando Gomes (1984, p. 39) continuaria a existir, e provavelmente, como objetiva a segurança nas relações jurídicas privadas, dificilmente será abandonada: "O que mais não se admite é o sentido absoluto que possuía”.

Assim, o hodierno Código Civil, inovou positivando a teoria da imprevisão, sob a forma da onerosidade excessiva, uma vez que o antigo estatuto civilista, preocupando-se apenas com a proteção do patrimônio associado à ampla vontade de contratar, não regulou expressamente a teoria da imprevisão, sendo esta encontrada apenas em artigos esparsos.

A sua aplicação, na vigência do Código Civil de 1916 era baseada na cautela. Aplicava-se somente a teoria da imprevisão em casos excepcionais, onde estivesse presente o fato imprevisível e extraordinário, acarretador de onerosidade excessiva (GONÇALVES, 2009).

O Código mudou. Todavia, os requisitos necessários para caracterizar a onerosidade excessiva continuam sendo os mesmos, com apenas uma particularidade inserida pelo legislador: o enriquecimento de uma parte em virtude do empobrecimento da outra.

Este último requisito é tido como impróprio para a grande parte dos estudiosos do direito. Ora, é perfeitamente possível a ocorrência de um fato externo imprevisível a álea contratual, gerador de excessiva onerosidade a uma das partes, sem que a outra seja beneficiada com isso. E mais, é cediço que ao invés de onerar apenas uma parte, o contrato pode se tornar excessivamente oneroso há ambos, e nesses casos, inaplicável seria o instituto frente a ausência de todos os seus requisitos?

Cabe acreditar que não.

A teoria da imprevisão trazida pelo Código Civil incrementada pelo requisito da onerosidade excessiva deve ser aplicada quando uma parte, ou ambas, encontrem dificuldades em cumprir o pactuado porque houve alteração do estado das coisas, ainda quando verificado que não houve enriquecimento de uma das 
partes. Nada mais é do que a incidências da antiga cláusula rebus sic stantibus, objetivando, claramente, preservar a dignidade humana da parte demasiadamente onerada. Como exigir, por exemplo, que em prejuízo do sustento seu e de sua família, o pactuante cumpra o contrato quando o fato responsável por onerá-lo deriva de acontecimentos imprevisíveis e extraordinários?

Ora, ninguém pode prever o imprevisível.

Nesses casos, incide a teoria da onerosidade excessiva. A parte estava, e continuaria a cumprir fielmente o contrato caso não sobreviesse o fato desencadeador da onerosidade excessiva. Nesse sentido, Orlando Gomes (1984, p. 199) aduz que "a onerosidade excessiva da prestação é apenas obstáculo ao cumprimento da obrigação. Não se trata, portanto, de inexecução por impossibilidade, mas de extrema dificuldade".

Ainda nesta seara, é válido mencionar que não é possível tecer considerações exatas sobre o que venha a integrar o conceito de fato imprevisível, uma vez que restou ao judiciário, quando instado acerca de casos concretos que requeiram a aplicação da teoria da onerosidade excessiva, a tarefa de aferir se um fato integra ou não a vala da imprevisibilidade.

\section{CONSIDERAÇ̃̃ES FINAIS}

Como se vislumbrou no presente estudo, o Estado Liberal foi resposta da burguesia relativamente à excessiva intervenção do Estado nas relações privadas. Para tanto, o direito acabou se desenvolvendo e foram revelados diversos institutos que eram considerados sacros, tais como a autonomia privada e o pacta sunt servanda. No início do século XX, com o surgimento do Estado do bem estar social acabou sendo necessário que este avocasse a função de diminuir o abismo social resultante da total ausência de intervenção.
Neste sentido, compulsando jurisprudências pátrias, insipientes ainda no assunto, é possível constatar que o desemprego e as alterações da economia não são tidos como fatos imprevisíveis para os aplicadores do direito, não cabendo, portanto, resolução ou revisão contratual fundada na clausula rebus sic stantibus em ambos os casos.

Ante o exposto, visualiza-se que o patrimonialismo apregoado e amplamente protegido pelo Código Civil de 1916, deu lugar a um direito civil preocupado com o bem estar social, com a função social do contrato, com a boa-fé e com a possibilidade de revisão ou resolução contratual quando, no decorrer do cumprimento do pacto, esses valores são perdidos.

O novel estatuto civilista corrobora aos valores trazidos pela Carta Magna de 1988, e passa a exigir que nas relações travadas entre os particulares se observe os direitos fundamentais, a dignidade da pessoa humana, permitindo que o pacto, tido como lei entre as partes até tempos atrás, pudesse ser modificado frente à ocorrência de situações inimagináveis no momento de sua celebração.

Desta feita, o antigo valor norteador e supremo dos contratos, a vontade, perdeu espaço em nossa sociedade com o advento da nova ordem constitucional. Isto porque, se não bastasse ser hierarquicamente superiores, as normas constitucionais, principalmente as referentes à dignidade da pessoa humana e os direitos fundamentais, visam a garantir uma dignidade mínima aos seres humanos, enquanto tal. 
Assim, novos valores foram introduzidos na ordem jurídica privada, culminando com o surgimento de princípios antes inexistentes (ou não positivados) e, também, princípios antigos, só que agora imbuídos de novos valores. Houve, então, uma mudança no âmago dos contratos, e todos os institutos com ele relacionados sofreram mudanças, passando a ter primazia à pessoa, em detrimento dos bens.

Destarte, atualmente, ainda que não haja preceitos infraconstitucionais expressos, acerca da incidência dos direitos fundamentais no campo privado, eles deverão ser aplicados. Entender o contrário constituiria flagrante inconstitucionalidade ou um enorme retrocesso, uma vez que a Constituição sanou qualquer dúvida acerca da eficácia horizontal dos direito fundamentais, apregoando em seu art. $5^{\circ}$ a sua máxima incidência.

Assim, havendo ou não omissão legislativa, será plenamente capaz ao aplicador do direito, analisando o caso apresentado, trazer à seara privada as normas oriundas do campo constitucional.

Acertada é esta previsão. Pois, as discussões travadas em âmbito particular, não poderiam ficar desprotegidas e serem regidas apenas pelo arbítrio dos pactuantes, pois, como se viu, foi este arbítrio e essa vontade desenfreada, que cavou o abismo social.

No mesmo sentido, imagine-se o infindável número de pactos que surgiram e tiveram que ser cumpridos por pessoas tidas como formalmente iguais, mas materialmente diferentes uma das outras. A igualdade conferida às pessoas nunca foi completa. Considerando abstrata e equivocadamente iguais formalmente, os poderosos passaram na realidade fática a impor sua vontade e a limitar a minimamente a vontade do outro.

Com efeito, vislumbra-se que a autonomia da vontade sofreu mudanças, perdendo as vestes que the atribuíam um valor absoluto. Sob esta ótica, visando o desenvolvimento das relações sociais, mas prevendo os acontecimentos futuros que, drasticamente poderiam alterar uma situação anteriormente estabelecida, que acredita-se ter sido o estopim para se positivar a teoria da imprevisão, hoje prevista no Código Civil sob o viés da onerosidade excessiva.

Contudo, urge trazer a lume que a previsão legal ainda não reverberou de maneira satisfatória no seio jurisprudencial, ao menos não nos tribunais superiores e nos tribunais de justiça. Pois, da análise dos poucos julgados existentes, se extraí que os magistrados encontram-se apegados a um enfoque estritamente legal, vistos através das lentes dos diplomas privados, conquanto a lente apta a possibilitar a escorreita visualização e aplicação da teoria da imprevisão, seria as do constitucionalismo fundado na dignidade da pessoa humana e nos direitos fundamentais.

Com isso, não se está apregoando a supressão da vontade e desconhecendo o seu valor na formação do contrato. Apenas acredita-se que os pactos, ainda que formados com base em uma vontade livre e, mesmo que ausente alguns dos requisitos necessários a aplicação da teoria em voga, possam ser revistos e, a depender do caso, resolvidos, com amparo no respeito ao ser humano, com fulcro, em sua dignidade.

Apenas está-se interpretando o diploma hierarquicamente inferior, com valores hierarquicamente superiores e, principalmente, fundamentais a existência de uma sociedade minimamente preocupada com os pares.

A autonomia da vontade, ou autonomia privada, jamais deixou de existir, e possivelmente, ainda que limitada, sempre existirá, uma vez que o contrato é fruto de vontades. Contudo, o que não se admite mais é a vontade desprovida de qualquer limite ou valores norteadores, sob pena de extrema vantagens a uns, e prejuízos imensuráveis a outros

Nesse caminho, a dignidade da pessoa humana, passou a ser o principal norte de todas as relações. 
Sendo este valor indispensável para a releitura de antigos institutos e princípios, absolutos sob a antiga ótica civilista. $E$, tendo em vista este valor, traz-se à tona a teoria da imprevisão e associa-se, aos direitos fundamentais, mesmo porque, acredita-se fielmente que outro não é o pilar.

Exigir esforços sobre humanos, para cumprir uma avença que se tornou benéfica a apenas uma das partes, por vezes até a nenhuma delas, seria indigno. Estar-se-ia fadando a ordem Constitucional e os seus valores supremos ao fracasso, caso institutos como a da onerosidade excessiva não fossem positivados. Isto porque, é este o fundamentado autorizador de intervenção judicial no âmbito privado.

De mais a mais, o mérito do legislador, falho em algumas áreas, nesta deve ser reconhecido uma vez que, além de positivar tal teoria, trouxe à baila princípios outros que, associados entre si ou, aplicados isoladamente, permitem uma maior personificação do contrato e, consequentemente, a incidência da dignidade da pessoa humana e dos diretos fundamentais, pois, percebeu-se que, o bem (economicamente aferível) deveria ceder lugar ao ser humano quando a obtenção daquele se tornasse demasiadamente onerosa a este.

À luz do exposto acima, acredita-se que, o fundamento primordial da teoria da onerosidade excessiva deve ser buscado em território constitucional, já que o pilar central que sustenta, hoje, a teoria da onerosidade excessiva, é a dignidade da pessoa humana cumulada com os direitos fundamentais. $E$, ainda que ausente um dos pressupostos autorizadores da aplicação da teoria da imprevisão, cabe defender a sua aplicação se assim se coadunar com os valores oriundos da dignidade, pois, a ultima ratio de qualquer norma, independente do seu patamar, deve ser o ser humano e o seu bem estar.

\section{REFERÊNCIAS}

ALEXY, Robert. Teoria dos direitos fundamentais. Trad. de Virgílio Afonso da Silva, São Paulo: Malheiros, 2006.

BOBBIO, Norberto. A era dos direitos, 6. ed. Rio de Janeiro: Elsevier, 2004.

CANOTILHO, J.J. Gomes. Direito constitucional e teoria da Constituição. Coimbra: ALMEDINA, 2003.

COMPARATO, Fábio Konder. Afirmação histórica dos direitos humanos. 7. ed. São Paulo: Saraiva, 2010.

DINIZ, Maria Helena. Curso de direito civil brasileiro: Teoria das obrigações contratuais e extracontratuais. Vol. 3. São Paulo: Saraiva, 2009.

FIUZA, César. Direito Civil: curso completo. 6. ed. Belo Horizonte: Del Rey, 2003.

GAGLIANO, Pablo Stolze; PAMPLONA FILHO, Rodolfo. Novo curso de direito civil. Volume IV - contratos. São Paulo: Saraiva, 2005.

GOMES, Orlando. Contratos. 13. ed. Rio de Janeiro: Forense, 1994. 
GONÇALVES, Carlos Roberto. Direito civil brasileiro. Volume III: contratos e atos unilaterais. 6. ed. São Paulo: Saraiva, 2009.

HESSE, Konrad. Temas fundamentais de direito constitucional. Tradução de: Carlos dos Santos Almeida, Gilmar Ferreira Mendes e Inocêncio Mártires Coelho. São Paulo: Saraiva. 2009.

LÔBO, Paulo Luiz Netto. Princípios sociais dos contratos no CDC e no Novo Código Civil. Revista jurídica da UNIRONDON, n. 3, 2002/1

MAURER, Béatrice. Notas sobre o respeito da dignidade da pessoa humana ... ou pequena fuga incompleta em torno de um tema central. In: SARLET, Ingo Wolfgang. (Org.). Dimensões da dignidade: Ensaios de filosofia do Direito e Direito constitucional. Tradução de Rita Dostral Zanini. Porto Alegre: Livraria do Advogado, 2009.

PENTEADO JUNIOR, Cassio M. C. 0 relativismo da autonomia da vontade e a intervenção estatal nos contratos. R. CEJ, Brasília, n. 23, p. 66-72, out./dez. 2003, disponível em: <http://www2.cjf.jus.br/ojs2/index.php/cej/article/ viewFile/579/759>. Acesso em: 02 fev. 2013.

PEREIRA. Jane Rios Gonçalves. Apontamentos sobre a aplicação das normas de direito fundamental nas relações jurídicas entre particulares. In: BARROSO, Luís Roberto (Org.). A nova interpretação constitucional: ponderação, direitos fundamentais e relações privadas. 3. ed. Rio de Janeiro: Renovar, 2008.

PIOVESAN, Flávia. Direitos Humanos e o Direito Constitucional Internacional. 10 ed. São Paulo: Saraiva, 2009.

PIOVESAN, Flávia. Temas de Direitos Humanos. São Paulo: Saraiva, 2010.

POLICARPO, Douglas. A incompatibilidade da dignidade afetiva e o direito à sucessão. Uma abordagem do reconhecimento da paternidade extemporânea. Jus Navigandi, Teresina, ano 11, n. 1256, 9 dez. 2006. Disponível em: <http://jus.com.br/revista/texto/9257>. Acesso em: 02 fev.2013.

RODRIGUES GOMES, Fábio. A eficácia dos direitos fundamentais na relação de emprego: algumas propostas metodológicas para a incidência das normas constitucionais na esfera juslaboral. Revista TST, Brasília, v.71, n.3, set/ dez 2005.

SARLET, Ingo Wolfgang. Dignidade da pessoa humana e direitos fundamentais na Constituição Federal de 1988. 8. ed. Porto Alegre: Livraria do advogado, 2010.

SILVA FILHO, Artur Marques da. Revisão judicial dos contratos. In: BITTAR, Carlos Alberto (Coord.). Contornos atuais da teoria dos contratos. São Paulo: Revista dos Tribunais, 1993.

TARTUCE, Flávio. Função social dos contratos: do Código de Defesa do consumidor ao Código Civil de 2002. São Paulo: Método, 2007 (coleção professor Rubens Limongi França, volume 2). 
TEPEDINO, Gustavo. Temas de Direito Civil. 3. a ed. Rio de Janeiro: Renovar, 2004.

VENOSA, Sílvio de Salvo. Direito civil: teoria geral das obrigações e teoria geral dos contratos. 3. ed. São Paulo: Atlas, 2003. Volume 2. 